\title{
The Effect of Nano-Additives on Diesel Engine Exhaust Emissions
}

\author{
Elżbieta Dobrzyńska ${ }^{1 *}$, Małgorzata Szewczyńska1, Bartosz Puchałka², \\ Andrzej Szczotka², Joseph Woodburn² \\ ${ }^{1}$ Central Institute for Labour Protection - National Research Institute, Warsaw, Poland \\ ${ }^{2}$ BOSMAL Automotive Research and Development Institute Ltd, Bielsko-Biala, Poland
}

\author{
Received: 20 January 2021 \\ Accepted: 25 May 2021
}

\begin{abstract}
Air pollution caused by diesel engines can have harmful effect not only on the environment but also on human health. Research carried out around the world aims at reducing the emission of particles and harmful chemical compounds during the operation of diesel engines, an example of which is the use of fuel nanomodifiers. In the study presented, the effect of two fuel additives available in Poland, containing cerium dioxide and ferrocene nanoparticles was investigated. Additives were added to standard European diesel fuel to evaluate their influence on the emission of particulate matter and selected chemical compounds in exhaust gases from a vehicle equipped with a compression-ignition engine. Measurements were carried out using the New European Driving Cycle (NEDC), on a chassis dynamometer, simulating real road traffic conditions. The results showed a reduction of carbon monoxide, hydrocarbons and particulate matter (both in terms of mass and number of particles) in the exhaust gases, but also a $2-4 \%$ increase in nitrogen oxide emissions. The use of such nanomodifiers in diesel fuel seems to be a promising solution, especially for older passenger cars commonly used on the roads, which are not regulated by the latest emission standards.
\end{abstract}

Keywords: nanoadditives, diesel fuel, diesel engine, exhaust emission, particulate matter, environmental pollution, road transport

\section{Introduction}

The increasing number of vehicles in the world and the environmental pollution caused by road transport have an undoubted impact on the increasing requirements for controlling emissions of harmful exhaust components. Road transport is often considered to be the main contributor to atmospheric emissions,

*e-mail: eleki@ciop.pl which pose a threat to both the environment and humans [1]. It should be stressed that combustion in a compression ignition (CI) engine is a complex physicochemical process, heterogeneous in the time and space domains. Diesel engine exhaust is a mixture of several hundred chemical compounds, formed as a result of incomplete combustion of diesel and engine oil, as well as the modifiers and impurities they contained [2]. Emissions and exhaust gas composition from diesel engines depend not only on the type, operating point and technical condition of the engine, but also on the 
composition and properties of the fuel and the exhaust after-treatment technology. A common phenomenon is the formation of photochemical smog over cities as a result of chemical reactions under the influence of solar radiation. Hydrocarbons make an essential contribution to the formation of ground-level ozone [2]. Black carbon particles, the major constituent of soot, are an undesirable by-product of combustion of diesel fuel, in particular from diesel engines driving heavy equipment, passenger cars, trucks, buses, railway locomotives and sea-going ships. Black carbon absorbs solar radiation and can thus heat the atmosphere, becoming a key contributor to global warming. The contribution of diesel-derived particulate emissions to climate change cannot be considered to be negligible [3-5]. Simultaneously, human exposure to diesel exhaust can cause eye, nose and throat irritation, but also acute and chronic changes in the respiratory and cardiovascular systems [6-8]. Moreover, diesel engine exhaust is considered by the International Agency for Research on Cancer (IARC) as mutagenic and carcinogenic (IARC cat. 1A). Efforts to reduce such pollution include the establishment of emission limit values for new vehicles sold in the European Union (EU). The EU standards comprise limit values for emissions of particulate, nitrogen oxides, carbon monoxide and hydrocarbons. At the same time, the emission limit values for these compounds are becoming increasingly stringent. Nowadays, the engines of new Diesel vehicles sold in the EU must emit $96 \%$ less nitrogen oxides than they were allowed to in 1990. Therefore, efforts to find compliance with these requirements remain ongoing, especially as they relate to older cars still present on the road.

Fuel modifications can assist in increasing engine efficiency and reducing emissions of harmful substances. According to Bafghi et al. [9], additives are an important part of the fuels currently in use. In the majority of research and experimental works conducted so far, it has been found that metal particles, both on a micro and nano-scale, when added to standard Diesel fuel and biodiesel, improve the ignition and combustion process $[10,11]$. Nano-additives (mainly metal oxides) increase the surface area-to-volume ratio, providing a larger contact surface area for rapid oxidation and more complete combustion, due to reduced ignition delays. Together with a carefully formulated base fuel composition, they can contribute to the efficiency and longevity of an engine [12].

This paper presents research on the influence of two different fuel modifiers, containing cerium dioxide and ferrocene nanoparticles, on the emission of particulate matter and hazardous chemical compounds from compression ignition engines. The use of these additives was briefly described in another paper by the authors [13], where the studies have been extended to emission of diesel oil mixture with addition of both nanomodifiers and hydrotreated vegetable oil (HVO).
Cerium dioxide $\left(\mathrm{CeO}_{2}\right)$ nanoparticles are mainly used as a fuel-borne catalyst in Diesel engines for the decomposition of unburnt hydrocarbons and carbonaceous particulate [14]. According to the literature, the presence of cerium can reduce the ignition temperature, thus facilitating the burning of carbon from the fuel within the engine cylinders, which further increases fuel efficiency and thus reduces particulate emissions [15]. These findings were confirmed by others, e.g. by Feroskhan et al. [16]. Nanoparticles of $\mathrm{CeO}_{2}$ exhibit high catalytic activity $[17,18]$. Their presence in diesel fuel may lead to simultaneous reductions in nitrogen dioxide and hydrocarbon emissions [18]. Particulate matter measurements from current technology diesel vehicles exhibit a high $(>80 \%)$ elemental carbon fraction [19].

Ferrocene is an organometallic chemical compound $\mathrm{Fe}\left(\mathrm{C}_{5} \mathrm{H}_{5}\right)_{2}$, an aromatic sandwich complex belonging to the metallocene group, in which the iron atom is located between two flat, parallel cyclopentadienyl rings [20]. Its stability at high temperatures and positive impact on fuel combustion efficiency have been described [2022], and thus also the impact on particulate emissions, namely a reduction thereof $[23,24]$. Ferrocene reduces the concentration of carbonaceous matter formed during combustion by more efficient burnout, rather than by inhibition of initial soot formation [21]. Its use in Diesel fuels may reduce Diesel particulate matter (DPM), but simultaneously change its physical and chemical properties, which may lead to changes in their toxicity [15]. A set of chemical reactions to predict engine behavior and combustion process that can aid efforts to reduce harmful combustion products was described by Sarath Chandra [22]. Zhang and Balasubramanian [15] made attempts to estimate the emission of particles after the addition of both nanoparticles of cerium dioxide and ferrocene to diesel. In their study, however, the nanoparticles' influence on harmful gaseous exhaust emissions was not investigated.

In light of the above, it was deemed of interest to obtain quantitative data on the impact of both nanoadditives on the emission of gaseous diesel exhaust components and particles. The search for solutions to reduce such emissions into the atmosphere is still an important issue taking into account concerns over oil resources and prices, climate change and traffic-related health effects. Due to the high share of passenger cars more than 10 years old on the roads [13], which has become a source of harmful exhaust emissions, it seems appropriate to seek solutions achieved via fuel modifications, since the cost and complexity of replacement (scrappage) and upgrading (emissions retrofitting) schemes are very high.

\section{Materials and Methods}

A commercial B7 fuel, i.e. Diesel oil with 7 percent admixture of bio-components Fatty Acid 
Methyl Esters (FAME), from Circle K, Poland and two commercially available nano-additives: Envirox ${ }^{\mathrm{TM}}$, a Diesel nanocatalyst (from Energenics Europe Ltd.) containing $2 \%$ cerium dioxide, with an average particle size $<8$ nanometers based on light distillates treated with hydrogen (crude oil), and ARCHOIL AR6900-D MAX Advanced Fuel Synthesis PD \& CR DIESEL, containing 5\% ferrocene $\left(\mathrm{Fe}\left(\mathrm{C}_{5} \mathrm{H}_{5}\right)_{2}\right)$ nanoparticles were used in the study. Based on the information from the safety datasheet, the AR6900-D MAX product is a mixture of 2-ethylhexyl nitrate (concentration: 25-50\%), naphtha solvent (petroleum), heavy aromatic hydrocarbons (10-20\%), C10-C13 hydrocarbons (n-Alkanes, isoalkanes, annular, aromatic $<2 \%$ ) (concentration: $4-8 \%$ ), 2-ethylhexan-1-ol $(<5 \%)$, 1,2,4-trimethylbenzene $(<5 \%)$, ferrocene $(<5 \%)$ and xylene $(<5 \%)$. Fuel blends of 20 liters each, based on B7 Diesel with and without nanomodifiers for fueling the compression-ignition engine, were prepared for testing on a chassis dynamometer and also analysed in terms of their physicochemical parameters. Market Diesel fuel containing $7 \%$ of bio-components, i.e. B7, was tested as a base fuel. Next, the fuel was mixed with the addition of nanomodifiers, i.e. cerium nanodioxide at a ratio of 1:4000 and, analogically, ferrocene at 1:1000, based on the manufacturers' suggestions.

Individual parameters of physicochemical fuel properties have been determined in accordance with the guidelines of the applicable ISO standards [25-33], which are presented in Table 1.

Emissions of harmful exhaust gas components were tested on a chassis dynamometer (AVL Zoellner, 48" 2WD type) working within the measurement range of $0-200 \mathrm{~km} / \mathrm{h}( \pm 0.05 \%$ accuracy $)$ in a laboratory professionally equipped to perform this type of test (Fig. 1). Exhaust emissions (both gaseous emissions and particulate) were measured using the New European Driving Cycle procedure specified in the European Directive 98/69/EC. This driving cycle represents driving in an urban area (UDC), followed by the Extra Urban Driving Cycle (EUDC). The UDC commences with a cold engine start, followed by 10 seconds of idling and then driving at speeds up to $50 \mathrm{~km} / \mathrm{h}$; for some $29 \%$ of the duration of the UDC the vehicle is at standstill (idling). Thus, the NEDC procedure captures the emissions associated with engine startup, idling and normal driving at a range of speeds up to $120 \mathrm{~km} / \mathrm{h}$. Measurements of regulated exhaust emissions i.e. carbon monoxide and carbon dioxide, nitrogen oxides and hydrocarbons (HC), as well as particle mass (PM) and particle number (PN) were carried out on a passenger vehicle. The test car (Fiat Panda, category M1) was equipped with a compressionignition engine meeting the Euro 3 emissions standard (without selective catalytic reduction (SCR) or a Diesel particulate filter (DPF)). The vehicle specifications were as follows: engine swept volume of $1248 \mathrm{~cm}^{3}$, maximum engine power of $51 \mathrm{~kW} @ 4000 \mathrm{rpm}$. The mileage at the start of testing was $121796 \mathrm{~km}$. The vehicle was fueled with Diesel fuel with or without a nanomodifier, the latter to provide a control.

In accordance with the NEDC procedure, the total sampling time was equal to the duration of the driving cycle, i.e. 1200 seconds. This sampling period is divided into two phases, the first of which (UDC) lasts 780 seconds and the second of which (EUDC) lasts

Table 1. Determined values of selected physicochemical properties of Diesel oil (B7) and its mixtures with nano-additives.

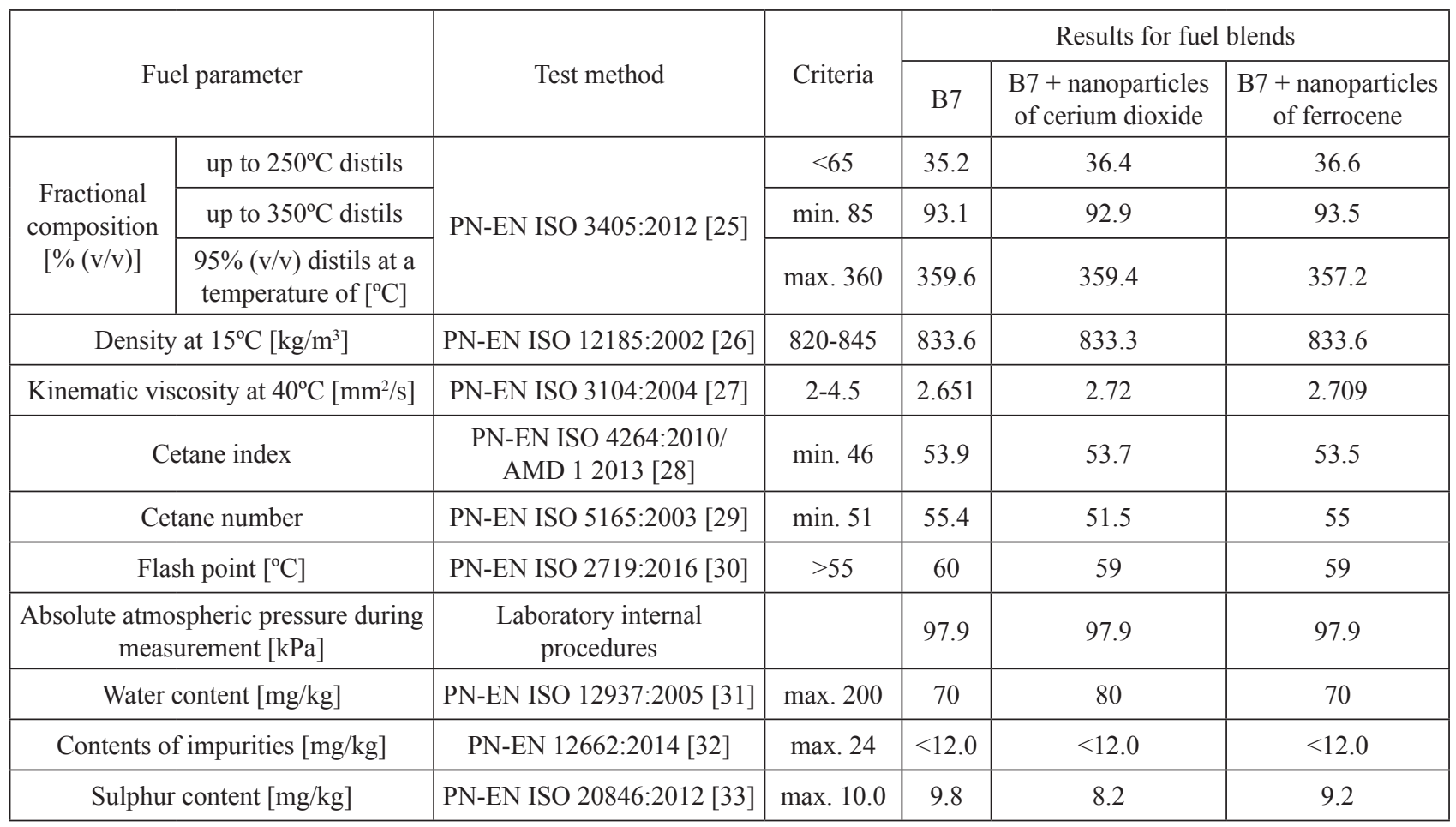




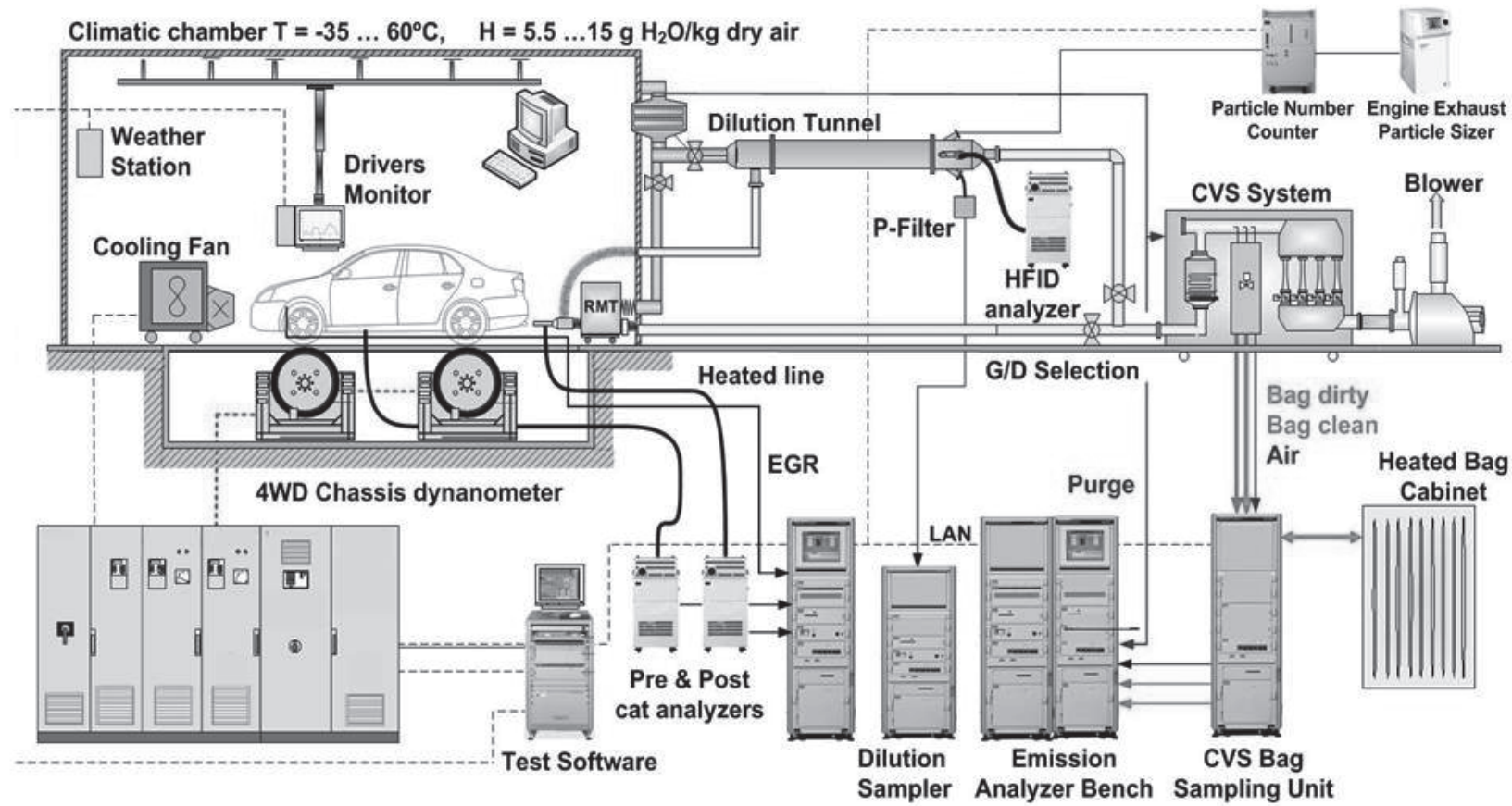

Fig. 1. Laboratory diagram with chassis dynamometer, exhaust gas collection and dilution system, exhaust gas analysers and particle number counter.

400 seconds. The sampling location was from the dilution tunnel of the exhaust emissions measurement system, in line with the NEDC procedure and standard practice in the automotive industry.

For the measurements of individual components of exhaust gases the following equipment, specified in the previous work of the authors [13], was used: for $\mathrm{CO}, \mathrm{CO}_{2}$ - non-diffuse absorption of infrared radiation (NDIR - non-dispersive infrared); HC - heated flame ionization detector (HFID) and $\mathrm{NO}_{\mathrm{x}}-$ chemiluminescent detector (CLD - chemiluminescent detector) with $\mathrm{NO}_{2} / \mathrm{NO}$ converter. In addition, for $\mathrm{CI}$ engines a heated gas path (with heated filters and pump) is required for emission measurement of THC - heated FID - heated flame ionisation analyser (HFID) at $190^{\circ} \mathrm{C}$ and for $\mathrm{NO}_{x}-110^{\circ} \mathrm{C}$ - heated CLD - heated chemiluminescent detector (HCLD). Particulate matter was quantified in terms of mass (gravimetric measurement performed by drawing a known volume of diluted exhaust gas through TX40 filters) and in terms of number (via a condensation particle counter measuring solid particles of diameter $>23 \mathrm{~nm}$ ). The measurements were carried out in full accordance with applicable legislation for the test vehicle type [34]. An exception to this point is that when the test vehicle was produced, the legislative test method did not include measurement of particle number - the measurement performed in this study is based on more recent legislative requirements applicable to newer vehicles. A detailed methodology of emission testing of harmful exhaust gas compounds on a chassis dynamometer, although commonly used for emissions testing in the automotive industry, has been previously described by Bielaczyc et al. [35].

\section{Results and Discussion}

\section{Determination of Physicochemical Parameters of Tested Fuels}

The physicochemical parameters of the fuels used in the presented study have been tested, covering cetane number and cetane index, fractional composition, sulphur, water and impurity content, as well as its viscosity and density, in accordance with the applicable ISO standards [25-33] (Table 1). The observed changes in the physicochemical properties of the resulting fuel mixtures did not affect the base fuel to such an extent that any modification of the engine was necessary. At the same time, the composition of the fuel and its physico-chemical properties, apart from the type of the engine and its technical condition, may affect the qualitative and quantitative nature of the exhaust emissions.

In the presented study the addition of nanoparticles of both ferrocene and cerium dioxide had little effect on the fractional composition of the mixtures. The presented results show that after the addition of nanomodifiers, the auto-ignition capability of the fuel decreased (taking into account both cetane number and cetane index). At the doses used in this study, cetane number decreased as much as 3.9 units with the addition of cerium nanodioxide, and by 0.4 units with the ferrocene nanoparticles added to the B7 fuel (Table 1). The studies of Chen [36] has shown that the impact of changes in cetane number in the range of 50-64 on emissions of NOx and particulates can be negligible. On the other hand, Balawender et al. [37] 
presented studies where a decrease of the derived cetane number resulted in reduction of hydrocarbons content in exhaust gases. Nano-additives had a small effect on the change in cetane index compared to base fuel B7 (differences of 0.2-0.4 units have been calculated). Viscosity and the combustion quality increased with the addition of nanomodifiers.

\section{Exhaust Emissions}

Exhaust emissions testing on a chassis dynamometer is one of the most important and complex tests to which combustion engine vehicles are subjected. The emissions were measured in the standard New European Driving Cycle (NEDC) test, separately in both the Urban Area (UDC) and the Extra Urban Driving Cycle (EUDC) phases. These tests were performed to enable analysis of the impact of fuel additives on the emissions of individual pollutants under different operating conditions. The obtained results (presented in Fig. 2) confirmed the effect of the nanomodifiers addition to Diesel fuel on the emission of exhaust components harmful to humans and the environment.

\section{Emissions of $\mathrm{CO}$ and $\mathrm{HC}$}

Exhaust emissions of $\mathrm{CO}$ and $\mathrm{HC}$ result from incomplete combustion and unburnt fuel [2]. A significant decrease in $\mathrm{CO}$ and $\mathrm{HC}$ emissions was observed in the NEDC tests with nanomodifier present in the fuel. Total hydrocarbons emissions decreased by $12.2 \mathrm{mg} / \mathrm{km}$ when nanoparticles of ferrocene were added to B7 fuel and by $2.5 \mathrm{mg} / \mathrm{km}$ with cerium dioxide nanoparticles. The reduction in $\mathrm{HC}$ when nanoparticles of cerium dioxide were present in the fuel was due to the conversion of $\mathrm{CeO}_{2}(+4)$ valance state to $\mathrm{CeO}_{3}$, which supplies enough oxygen for complete combustion of hydrocarbons and the conversion of cerium oxide to cerous oxide, as previously described by Saxena et al. [38]. Much higher emissions during the urban driving cycle than the EUDC were noticed for $\mathrm{CO}$ and total hydrocarbons. Carbon monoxide is produced in the process of combustion with insufficient oxygen. High $\mathrm{CO}$ emission in the UDC phase results from a worsened combustion process in the cold engine, as well as from the fact that the after-treatment system (in this case, a Diesel oxidation catalyst) is inactive, not having yet warmed up. Thus, in the UDC phase the production of $\mathrm{CO}$ in the engine is elevated and the ability of the after-treatment system to deal with those emissions is compromised. In the EUDC phase, the engine and its after-treatment has already reached thermal stabilization, which significantly reduces the formation of $\mathrm{CO}$ in the combustion process and greatly increases the ability of the after-treatment to eliminate emissions, and so the $\mathrm{CO}$ emissions reach a relatively constant, low level.

\section{Emissions of NOx}

Emissions of $\mathrm{NO}_{\mathrm{x}}$ increased, both after adding nanoparticles of cerium dioxide (increase by $10.9 \mathrm{mg} /$ $\mathrm{km}$ ) and ferrocene (by $6.2 \mathrm{mg} / \mathrm{km}$ ) to B7 fuel. Such an increase in $\mathrm{NO}_{\mathrm{x}}$ emission can be probably explained by the catalytic effect of metallic additives on the combustion process. The $\mathrm{NO}_{\mathrm{x}}$ emission results for all tested fuel blends are in the range of $280-295 \mathrm{mg} / \mathrm{km}$ (in the UDC phase even at a level of $409 \mathrm{mg} / \mathrm{km}$ ), thus complying with the Euro $3 \mathrm{NOx}$ emission limit $(500 \mathrm{mg} / \mathrm{km})$. However, in relation to the current Euro 6 standard, which limits $\mathrm{NO}_{\mathrm{x}}$ emissions from vehicles with Diesel engines to a level of only $80 \mathrm{mg} / \mathrm{km}$,

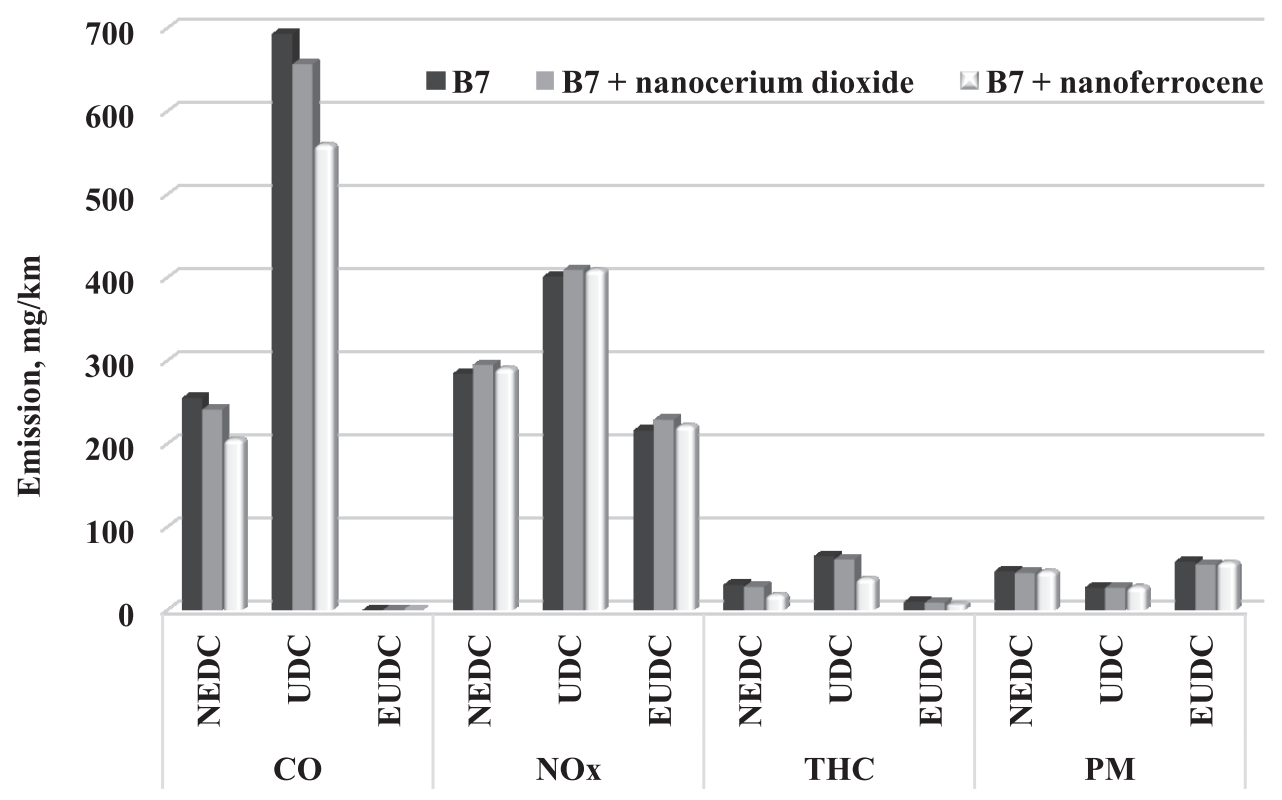

Fig. 2. Differences in gaseous and particulate emissions with the addition of nanomodifiers to B7 fuel. 
these values are very high. In the extra-urban EUDC phase, both ferrocene and cerium dioxide nanoparticles present in $\mathrm{B} 7$ fuel contributed to an increase in $\mathrm{NO}_{\mathrm{x}}$ concentrations in the exhaust gas. The analysis of physicochemical parameters of individual fuels may lead to the conclusion that the lowest $\mathrm{NO}_{\mathrm{x}}$ emission values should be expected for the mixture with the highest cetane number. With an increase in cetane number, the amount of fuel burned in the kinetic phase decreases, while the amount burned in the diffusion phase increases. The formation of $\mathrm{NO}_{\mathrm{x}}$ is determined by the amount of fuel burned in the kinetic phase.

\section{Particulate Emissions}

Measurements of the mass of particulate matter emitted on a dynamometer are carried out using a gravimetric method using a CVS and dilution tunnel. As determined by exhaust emissions measurements in the NEDC test, the addition of nanomodifiers caused a reduction of PM mass emissions [mg/km] (Fig 3). Lower values of PM emissions were recorded after the use of B7 fuel doped with $\mathrm{CeO}_{2}$ nanoparticles $(5 \%$ emission reduction) than ferrocene nanoparticles. Much higher emissions were observed for PM during the EUDC than the UDC. It should be emphasized that compared to Euro 3 requirements (Commission Regulation (EU) 98/69/EC), PM emissions did not exceed the applicable limit of $50 \mathrm{mg} / \mathrm{km}$. However, these results significantly exceeded the Euro 5 and Euro 6 standards (Commission Regulation (EU) 459/2012) in force today, where the limit value is over ten times lower $(4.5 \mathrm{mg} / \mathrm{km})$. What is more, current EU regulations limit particulate emissions by both mass and number. The Euro $5+$ standard introduced a new requirement: a particle number (PN) limit which can be emitted per $\mathrm{km}$ for all passenger cars and vans with CI engines, which is $6 \times 10^{11}[\# / \mathrm{km}]$. This PN limit is much more demanding compared to the mass (PM) limit, making PN measurements the main focus of automotive particulate testing today. Particle number limits complement the mass limits, involving the use of other measurement methods. For legislative purposes, PN measurement is carried out from the diluted exhaust gas, with the sample obtained from the aforementioned dilution tunnel. Solid particles between $23 \mathrm{~nm}$ and $2.5 \mu \mathrm{m}$ are measured. The introduction of a PN limit was dictated by the results of toxicological studies indicating that the negative impact on human health is relatively more determined by the number and size (and thus surface area) of the emitted particles than by their mass. The finest particles may have a small share in the total mass of particles, but they can penetrate further into the lungs and are much more likely to get into the bloodstream.

The number of particles measured in diesel exhaust reached several tens of trillions per $\mathrm{km}$ and differed from each other for the two fuel blends. The presence of cerium dioxide reduced the number of particles in diesel exhaust (to $6.77 \times 10^{13} / \mathrm{km}$ ), while ferrocene caused smaller changes (up to $7.132 \times 10^{13} / \mathrm{km}$ ) compared to B7 fuel. The results obtained revealed opposing trends to those reported by Zhang et al [15]. That study found that diesel fuel admixtures with $\mathrm{CeO}_{2}$ and $\mathrm{Fe}\left(\mathrm{C}_{5} \mathrm{H} 5\right)_{2}$ nanoparticles as fuel catalysts, although effective in reducing PM mass emissions, led to a significant increase in particulate matter. During the EUDC phase, when the engine is fully warmed up, a much stronger correlation between PM and PN values can be observed. The influence of physicochemical parameters on PM emission in the exhaust gases is visible in the second part of the test - the EUDC phase. It is connected, among others, with higher engine load in this phase of the test.

\section{$\mathrm{CO}_{2}$ Emissions}

One of the most important challenges for our civilization is the fight against global warming by reducing anthropogenic greenhouse gas emissions into the atmosphere. Targets are to reduce $\mathrm{CO}_{2}$ emissions by $20 \%$ by 2020 and $50 \%$ by 2050 . Road transport is currently one of the largest sources of $\mathrm{CO}_{2}$ emissions in the European Union. $\mathrm{CO}_{2}$ emissions can be regarded as being proportional to the fuel consumed in the operation of the vehicle [34]. Directive 93/116/EC and Regulation 101 [39], among others provide for the measurement of carbon dioxide emissions and fuel consumption based on $\mathrm{CO}, \mathrm{CO}_{2}$ and $\mathrm{HC}$ emissions in the NEDC laboratory test. The result of the measurement is presented as the total $\mathrm{CO}_{2}$ emissions (for both parts of the test), expressed in $\mathrm{g} / \mathrm{km}$ and fuel consumption expressed in $\mathrm{dm}^{3} / 100 \mathrm{~km}$. The value of fuel consumption (FC) can be determined separately for both parts of the test and jointly for the entire test, based on the formula [39]:

$$
\begin{gathered}
\mathrm{FC}=0.1155 / \rho_{\mathrm{F}} \times(0.886 \times[\mathrm{HC}]+0.429 \times[\mathrm{CO}] \\
\left.+0.273 \times\left[\mathrm{CO}_{2}\right]\right)
\end{gathered}
$$

...where $\rho_{\mathrm{F}}$ is the density of the fuel.

Lower fuel consumption leads to lower $\mathrm{CO}_{2}$ emissions. Table 2 presents the results of $\mathrm{CO}_{2}$ emissions measurements, fuel consumption and vehicle mileage in the NEDC test and separately in both its EDC and EUDC phases. The results showed that the differences in $\mathrm{CO}_{2}$ emissions in the NEDC test using individual B7 blends with or without a nanomodifier as a fuel are within the limits of 1-3\%, as is the fuel consumption. Higher values of emissions $[\mathrm{g} / \mathrm{km}]$ were observed in the urban phase of UDC, which, similarly to CO emissions, is due to deteriorated combustion process caused by the lack of thermal stabilization of the engine. It can also be caused by moving the vehicle at suboptimal speeds in low gears and frequent stops and idling.

\section{Directions for Further Research, Practice and Policy}

Increasingly stringent regulations (exhaust emissions standards) for pollutant emissions require extensive 
Table 2. Fuel consumption and $\mathrm{CO}_{2}$ emission results in the NEDC test.

\begin{tabular}{|c|c|c|c|c|c|c|c|}
\hline \multirow{2}{*}{ Fuel mixture } & \multirow{2}{*}{$\begin{array}{l}\text { Measurement (vehicle mileage } \\
[\mathrm{km}])\end{array}$} & \multicolumn{3}{|c|}{ Emission of $\mathrm{CO}_{2}[\mathrm{~g} / \mathrm{km}]$} & \multicolumn{3}{|c|}{ Fuel consumption [1/100 km] } \\
\hline & & NEDC & UDC & EUDC & NEDC & UDC & EUDC \\
\hline \multirow{4}{*}{ B7 } & $1(122006)$ & 124.6 & 148.9 & 110.4 & 4.73 & 5.69 & 4.18 \\
\hline & $2(122017)$ & 124.2 & 148.1 & 110.3 & 4.72 & 5.65 & 4.17 \\
\hline & mean & 124.4 & 148.5 & 110.4 & 4.72 & 5.67 & 4.18 \\
\hline & Standard deviation A & 0.2 & 0.5 & 0.1 & 0.01 & 0.03 & 0.01 \\
\hline \multirow{4}{*}{$\begin{array}{l}\mathrm{B} 7+\text { nanoparticles } \\
\text { of cerium dioxide }\end{array}$} & $1(122054)$ & 125.7 & 150.3 & 111.4 & 4.77 & 5.73 & 4.22 \\
\hline & $2(122065)$ & 125.6 & 150.1 & 111.3 & 4.77 & 5.73 & 4.21 \\
\hline & mean & 125.6 & 150.2 & 111.4 & 4.77 & 5.73 & 4.21 \\
\hline & Standard deviation A & 0.1 & 0.2 & 0.1 & 0.01 & 0.01 & 0.01 \\
\hline \multirow{4}{*}{$\begin{array}{l}\text { B7 + nanoparticles } \\
\text { of ferrocene }\end{array}$} & $1(122127)$ & 123.1 & 147.2 & 109.1 & 4.67 & 5.60 & 4.13 \\
\hline & $2(122175)$ & 122.8 & 147.4 & 108.6 & 4.66 & 5.61 & 4.11 \\
\hline & mean & 122.9 & 147.3 & 108.8 & 4.66 & 5.61 & 4.12 \\
\hline & Standard deviation A & 0.2 & 0.2 & 0.4 & 0.01 & 0.01 & 0.01 \\
\hline
\end{tabular}

research, design, approval, and thus also control and diagnosis work in the field of exhaust gas emissions and their mitigation. One way to improve combustion of fuel in a diesel engine without changing its base specification is to introduce a chemical additive. Fuel modifications play an important role in increasing engine performance and reducing emissions of substances that pose a risk to human health. Efforts made to reduce emissions by introducing new emissions standards (i.e. limit values for several chemical compounds and particles in the exhaust) may not fully solve the problem, as they only concern newly manufactured vehicles. Crucially, newer standards do not apply to vehicles already on the road - and therefore do not fully address the problem of diesel exhaust pollution. This study is a good step towards the application of fuel modifications and finding their potential for reducing emissions from passenger cars on the EU's roads. Nevertheless, further research in this direction is required. Comparative studies of $\mathrm{CeO}_{2}$ nanoparticles with other nanoparticles should be conducted, in order to have a comprehensive evaluation and approach [17]. Future research should also further investigate the effects of cerium dioxide and ferrocene nanoparticles on exhaust emissions, human health and the environment. The main challenge for the future will therefore be to fully assess the potential harmful effects on the environment and health associated with the release of nanoadditives and nanoadditive-derived compounds, while exploring the extent to which these nanoadditives can improve current GHG emission factors. As presented by Biglari et al. [40], decreasing emissions from fuel combustion, creating green space, planning and cooperation of all responsible organizations can be effective in decreasing the effect of such pollutants on air quality and human health.

\section{Conclusions}

The addition of cerium nanodioxide to B7 fuel resulted in a reduction of carbon monoxide emissions (by $5 \%$ ), hydrocarbons (by $8 \%$ ), as well as the mass and number of particles (by $5 \%$ ). At the same time, however, an increase in the emission of nitrogen oxides (4\%) and carbon dioxide $(1 \%)$ was observed. It confirmed that particles and nitrogen oxides (NOx) were generated antagonistically. Thus smaller amount of particles were produced at the expense of larger amount of $\mathrm{NOx}$ formation. This is a manifestation of the well-known PM-NOx tradeoff effect.

The addition of ferrocene nanoparticles to B7 base fuel showed a $20 \%$ reduction in carbon monoxide and even by $40 \%$ in hydrocarbons. Lower differences were observed in the case of particles emissions. The authors observed an increase in mass of particles by $0.68 \mathrm{mg} / \mathrm{km}$ and decrease in their number PN $<1 \%$. Simultaneously, an increase in nitrogen oxides emission by $7.94 \mathrm{mg} / \mathrm{km}$ was noted. Moreover, unlike the addition of cerium nanodioxide, ferrocene nanoparticles caused a decrease in carbon dioxide emissions (by $1.5 \mathrm{~g} / \mathrm{km}$ ) and fuel consumption. Both nanomodifiers had a similar effect on fuel consumption.

The obtained results allow us to conclude that the application of nano-additives to B7 diesel oil, such as ferrocene or cerium dioxide, will reduce the emission of carbon monoxide, hydrocarbons and particles in the air. From the point of view of environmental pollution and its impact on human health, these results are promising, but require further work in this direction. The average passenger car in Poland is over a dozen years old and thus it meets the requirements of the Euro 3-Euro 4 standard on average. Since there is no accurate information on deregistered or unused cars, 
it can be expected that poor air quality will continue to be a problem and vehicular pollution will have a harmful impact on human health. Hence, the use of diesel nanomodifiers seems to be a good solution, especially for older in-use cars not subject to the most recent emissions standards (Euro 6). So far, the reduction of particles emissions from the transport sector could be achieved via the use of diesel particulate filters for onroad and off-road vehicles, as well as by eliminating high-emitting diesel vehicles from circulation. This study has shown that the addition of nanoparticles of cerium dioxide can reduce particulate matter emissions by up to $7 \%$.

\section{List of Abbreviations}

B7 - Diesel containing 7\% biocomponents (biodiesel) by volume

NEDC - New European Driving Cycle

UDC - Urban Driving Cycle

EUDC - Extra-Urban Driving Cycle

IARC - International Agency for Research on Cancer

EU - European Union

$\mathrm{CO}$ - carbon monoxide

$\mathrm{CO}_{2}$ - carbon dioxide

$\mathrm{CPC}$ - condensation particle counter

DOC - diesel oxidation catalyst

DPF - diesel particle filter

EC - elemental carbon

EGR - exhaust gas recirculation

EN590 - standard diesel fuel

FAME - fatty acid methyl ester

GHG - greenhouse gases

$\mathrm{HC}$ - hydrocarbon

$\mathrm{NO}$ - nitrogen monoxide

$\mathrm{NOx}$ - nitrogen oxides

NRSC - non-road steady cycle

$\mathrm{PAH}$ - polycyclic aromatic hydrocarbon

PM - particulate matter

$\mathrm{PN}$ - particle number

FC - fuel consumption

SCR - selective catalytic reduction

NDIR - non-dispersive infra-red

CLD - chemiluminescence detector

HCLD - chemiluminescence detector

AVL - AVL List GmbH (company)

FID - flame ionization detector

HFID - heated flame ionization detector

IC - internal combustion engine

NPs - nanoparticles

BP - brake power

$\mathrm{CI}$ - compression ignition

$\mathrm{CeO}$ - cerium oxide

ppm - parts per million

$\mathrm{nm}$ - nanometer

\section{Acknowledgments}

This paper has been based on the results of a research task carried out within the scope of the fourth stage of the National Programme "Improvement of safety and working conditions" supported in 20172019 - within the scope of research and development - by the Ministry of Science and Higher Education/ National Centre for Research and Development. The Central Institute for Labour Protection National Research Institute is the Programme's main co-ordinator.

\section{Conflict of Interest}

The authors declare no conflict of interest.

\section{References}

1. NEISI A., VOSOUGHI M., SHIRMARDI M., IDANI E., GOUDARZI G., HAZRATI S., MOHAMMADI M.J., ASADI A., ASGHARNIA H., HASHEMZADEH B., GHAED RAHMAT Z. Concentration of air pollutants as toxic matter in urban and rural areas of Ahvaz. Toxin Rev., 37 (3), 243, 2018.

2. REŞITOĞLU İ.A., ALTINIŞIK K., KESKIN A. The pollutant emissions from diesel-engine vehicles and exhaust after-treatment systems, Clean Technol. Envir. Policy, 17, 15, 2015.

3. MODAK N.M., GHOSH D.K., PANDA S., SANA S.S. Managing greenhouse gas emission cost and pricing policies in a two-echelon supply chain. CIRP J. Manuf. Sci. Technol., 20, 1, 2018.

4. DAMANIK N., ONG H.C., TONG C.W. INDRA MAHLIA T. M., SILITONGA A.S. A review on the engine performance and exhaust emission characteristics of diesel engines fueled with biodiesel blends. Environ. Sci. Pollut. Res., 25, 15307, 2018.

5. WANG X., WANG Y., BAI Y., WANG P., ZHAO Y., An overview of physical and chemical features of diesel exhaust particles. J. Energy Inst., 92 (6), 1864, 2019.

6. ABRAMESKO V., TARTAKOVSKY L., Ultrafine particle air pollution inside diesel-propelled passenger trains. Environ. Pollut., 226, 288, 2017.

7. MUNOZ X., BARREIRO E., BUSTAMANTE V., LOPEZCAMPOS J.L., GONZALEZ-BARCALA F.J., CRUZ M.J., Diesel exhausts particles: Their role in increasing the incidence of asthma. Reviewing the evidence of a causal link. Sci. Total Environ., 652, 1129, 2019.

8. DASTOORPOOR M., RIAHI A., YAZDANINEJHAD H., BORSI S.H., KHANJANI N., KHODADADI N., MOHAMMADI M.J., AGHABABAEIAN H., Exposure to particulate matter and carbon monoxide and cause-specific Cardiovascular-Respiratory disease mortality in Ahvaz. Toxin Rev., 1, 2020.

9. BAFGHI A.A.T., BAKHODA H., CHEGENI F.K. Effects of Cerium Oxide Nanoparticle Addition in Diesel and Diesel-Biodiesel Blends. Int. J. Mech. Mechat. Eng., 9 (8), 1415, 2015.

10. KHOND, V., KRIPLANI, V. M. Effect of nanofluid additives on performances and emissions of emulsified 
Diesel and bioDiesel fueled stationary CI engine: A comprehensive review. Renewable Sustainable Energy Rev., 59, 1338, 2016.

11. SOUDAGAR M. E. M., NIK-GHAZALI N.-N., KALAM MD. A., BADRUDDIN I.A., BANAPURMATH N.R., AKRAM N. The effect of nano-additives in dieselbiodiesel fuel blends: A comprehensive review on stability, engine performance and emission characteristics, Energy Convers. Manage., 178, 146, 2018.

12. HATAMI M., HASANPOUR M., JING D., Recent developments of nanoparticles additives to the consumables liquids in internal combustion engines: Part I: Nano-fuels. J. Mol. Liq., 318, 114250, 2020.

13. DOBRZYŃSKA E., SZEWCZYŃSKA M., POŚNIAK M., SZCZOTKA A., PUCHAŁKA B., WOODBURN J. Exhaust emissions from diesel engines fueled by different blends with the addition of nanomodifiers and hydrotreated vegetable oil HVO. Environ. Pollut., 259, 113772, 2020.

14. MANDAL S., KANAGARAJ S. Reduction of Emission in a Diesel Engine Using Nanofuel - Ceria Nanoparticle Dispersed Diesel. J. ASTM Int., 9 (5), 1, 2012.

15. ZHANG Z.H., BALASUBRAMANIAN R. Effects of Cerium Oxide and Ferrocene Nanoparticles Addition As Fuel-Borne Catalysts on Diesel Engine Particulate Emissions: Environmental and Health Implications. Environ. Sci. Technol., 51 (8), 4248, 2017.

16. FEROSKHAN M., ISMAIL S., GOSAVI S., TANKHIWALE P., KHAN Y. Optimization of performance and emissions in a biogas-diesel dual fuel engine with cerium oxide nanoparticle addition. Proc. Inst. Mech. Eng., Part D: J. Automob. Eng., 233 (5), 1178, 2019.

17. HOANG A. T., Combustion behavior, performance and emission characteristics of diesel engine fueled with biodiesel containing cerium oxide nanoparticles: A review. Fuel Process. Technol., 218, 106840, 2021.

18. SAJEEVAN A.C., SAJITH V. Diesel Engine Emission Reduction Using Catalytic Nanoparticles: An Experimental Investigation. J. Eng., 2314, 2013.

19. GIECHASKIEL B., MARICQ M., NTZIACHRISTOS L., DARDIOTIS C., WANG X., AXMANN H., BERGMANN A., SCHINDLER W., Review of motor vehicle particulate emissions sampling and measurement: From smoke and filter mass to particle number. J. Aerosol Sci., 67, 48, 2014.

20. PAL A., RANJAN BHATTA S., THAKUR A., Recent advances in the development of ferrocene based electroactive small molecules for cation recognition: A comprehensive review of the years 2010-2020. Coord. Chem. Rev., 431, 213685, 2021.

21. NASH D., SWANSON N., PRESTON W., YELVERTON T., ROBERTS W., WENDT J., LINAK W. Environmental implications of iron fuel borne catalysts and their effects on Diesel particulate formation and composition. J. Aerosol Sci., 58, 50, 2013.

22. SARATH CHANDRA M., MADHU S. Effect of Ferrocene as a Fuel Additive on Four Stroke Diesel Engine Performance. Int. J. Modern Eng. Res., 2016.

23. ELWARDANY A.E., MAREI M.N., ELDRAINY Y., ALI R.M., ISMAIL M., EL-KASSABY M.M. Improving performance and emissions characteristics of compression ignition engine: Effect of ferrocene nanoparticles to dieselbiodiesel blend. Fuel, 270, 117574, 2020.

24. CHAO H., LI W., LIN Q., CHENG X., HUANG Q., ZHANG H., WANG Z., DAVID G. Effects of ferrocene on flame temperature, formation of soot particles and growth of polycyclic aromatic hydrocarbons. J. Energy Inst., 90 (6), 893, 2017.

25. PN EN ISO 3405:2012 Petroleum Products - Determination of Distillation Characteristics at Atmospheric Pressure (ISO 3405:2011)

26. PN EN ISO 12185:2002 Crude Petroleum and Petroleum Products - Determination of Density - Oscillating U-Tube Method.

27. PN EN ISO 3104:2004 Petroleum Products - Transparent and Opaque Liquids - Determination of Kinematic Viscosity and Calculation of Dynamic Viscosity.

28. PN EN ISO 4264:2010 AMD 12013 Petroleum Products Calculation of Cetane Index of Middle-Distillate Fuels by Four-Variable Equation (ISO 4264:2007/AMD 1:2013).

29. ISO 5165:2003 Petroleum products - Determination of the ignition quality of diesel fuels - Cetane engine method.

30. ISO 2719:2016 Determination of Flash Point - PenskyMartens Closed Cup Method.

31. PN EN ISO 12937:2005 Petroleum Products Determination of Water - Coulometric Karl Fischer Titration Method.

32. PN EN 12662:2014 Liquid Petroleum Products Determination of Total Contamination in Middle Distillates, Diesel Fuels and Fatty Acid Methyl Esters.

33. PN EN ISO 20846:2012 Petroleum Products Determination of Sulfur Content of Automotive Fuels Ultraviolet Fluorescence Method (ISO 20846:2011)

34. UNECE Regulation 2015, Regulation No 83 of the Economic Commission for Europe of the United Nations (UNECE) - Uniform provisions concerning the approval of vehicles with regard to the emission of pollutants according to engine fuel requirements [2015/1038]

35. BIELACZYC P., SZCZOTKA A., KLIMKIEWICZ D., Wpływ analizatorów spalin na wyniki emisji oraz analiza możliwości zwiększenia dokładności pomiarów emisji gazowych związków szkodliwych spalin przez zastosowanie nowoczesnych analizatorów pod kątem badania samochodów o bardzo niskiej emisji. Technika Transportu Szynowego, 12, 131, 2015 [In Polish].

36. CHEN W., SHUAI S., WANG J., Effect of the Cetane Number on the Combustion and Emissions of Diesel Engines by Chemical Kinetics Modeling. Energy \& Fuels, 24 (2), 856, 2010.

37. BALAWENDER K., KONIECZNY D., KUSZEWSKI H., LEJDA K., LEW K., WOJEWODA P., The effect of physicochemical properties of fuels on ecological parameters of a diesel engine. Combust. Engines, 171 (4), 274, 2017.

38. SAXENA V., KUMAR N., SAXENA V.K., A comprehensive review on combustion and stability aspects of metal nanoparticles and its additive effect on diesel and biodiesel fuelled C.I. engine. Renewable Sustainable Energy Rev., 70, 563, 2017.

39. UNECE Regulation 2007, Regulation No 101 of the Economic Commission for Europe of the United Nations (UN/ECE) (2019).

40. BIGLARI H., GERAVANDI S., MOHAMMADI M.J., PORAZMEY E.J., CHUTURKOVA R.Z., KHANIABADI Y.O., GOUDARZI G., MAHBOUBI M., MOHAMMADI B., YARI A.R., Relationship between air particulate matter and meteorological parameters. Fresenius Environ. Bull., 26 (6), 4047, 2017. 